\title{
Analysis of Cerebrospinal Fluid (CSF) - Adenosine Deaminase (ADA) in Meningitis
}

\author{
Akkamahadevi V. Nipanal ${ }^{1}$, Madhukumar M.H², Nagappa H. ${ }^{3}$ \\ 1, 2, 3 Department of General Medicine, Bangalore Medical College \& Research Institute, \\ Bangalore, Karnataka, India.
}

\section{ABSTRACT}

\section{BACKGROUND}

Acute infections of the nervous system are generally widespread and cause significant problems in the field medicine and therefore early detection, right decision making, and early initiation of therapy can be lifesaving. Meningitis is the inflammation of the membranes that cover the brain and spinal cord. It is a general clinical problem during infancy and childhood. Delay in differentiating between bacterial, tubercular \& viral meningitis and institution of its treatment may have irreparable consequences that lead to significant morbidity \& mortality. The present study was conducted to find out the utility of cerebrospinal fluid-adenosine deaminase (CSF-ADA) for the early diagnosis \& differentiation of tubercular \& viral meningitis in adults.

\section{METHODS}

50 meningitis patients who met the inclusion criteria were selected. Investigations including complete haemogram, liver function test (LFT), renal function test (RFT), random blood sugar (RBS), serum electrolytes, human immunodeficiency virus (HIV) test, chest x-ray and computed tomography (CT) brain (plain) were done. CSF cytology, biochemistry, gram stain, acid-fast bacteria (AFB) stain \& culture were done. These cases were further divided in to two groups based on clinical and CSF laboratory findings as group I: tubercular meningitis, group II: viral meningitis. An estimation of CSF-ADA was done in all patients.

\section{RESULTS}

The mean age of the 50 patients studied was $37.76 \pm 15.58$ years, with the maximum number of patients suffering from tubercular meningitis. The incidence of meningitis was more in males. CSF-adenosine deaminase activity was found to be higher in tubercular meningitis, the mean value was $17.67 \pm 8.13 \mathrm{IU} / \mathrm{L}$.

\section{CONCLUSIONS}

Assessment of CSF-ADA will be helpful for early diagnosis and differentiation of tubercular and viral meningitis. This is needed when gold standard investigations for meningitis like smear and / or culture for acid fast bacilli are not available or negative or are time consuming.

\section{KEY WORDS}

CSF-Cerebrospinal Fluid, ADA-Adenosine Deaminase, AFB-Acid Fast Bacilli.
Corresponding Author: Dr. Akkamahadevi V. Nipanal, District Hospital, Haveri-581110, Karnataka, India.

E-mail: akdevi89@gmail.com

DOI: $10.14260 /$ jemds/2021/236

How to Cite This Article:

Nipanal AV, Madhukumar MH, Nagappa H. Analysis of cerebrospinal fluid (CSF) Adenosine deaminase (ADA) in meningitis. J Evolution Med Dent Sci 2021;10(16): 1102-1105, DOI:

10.14260/jemds/2021/236

Submission 27-11-2020,

Peer Review 19-02-2021,

Acceptance 26-02-2021,

Published 19-04-2021.

Copyright (C) 2021 Akkamahadevi V. Nipanal et al. This is an open access article distributed under Creative Commons Attribution License [Attribution 4.0 International (CC BY 4.0)] 


\section{BACKGROUND}

Acute infections of the nervous system are among the most important problems in medicine because early recognition, efficient decision making, and rapid institution of therapy can be lifesaving. These distinct clinical syndromes include acute bacterial meningitis, viral meningitis, encephalitis, focal infections such as brain abscess and subdural empyema, and infectious thrombophlebitis. ${ }^{1}$ Meningitis is an inflammation of the membranes that covers the brain and spinal cord. It is a widespread clinical problem in the period of infancy and childhood. Delay in distinguishing between bacterial, tubercular \& viral meningitis \& treatment may have irretrievable problems that lead to considerable morbidity \& mortality..$^{2,3}$

Tuberculous meningitis may develop intensely with severe headache, confusion, lethargy, altered sensorium and neck rigidity. Naturally, the disease evolves over $1-2$ weeks, a course longer than that of bacterial meningitis. As meningeal involvement is prominent at the base of the brain, paresis of cranial nerves (ocular nerves in particular) is a common finding, and the involvement of cerebral arteries may yield focal ischemia. The eventual evolution is toward coma, with hydrocephalus and intracranial hypertension. 4 Tuberculoma, an uncommon manifestation of central nervous system tuberculosis, presents as one or more space- occupying lesions and usually causes seizures and focal signs. ${ }^{4}$

Viral meningitis usually results in a benign and selflimiting illness requiring no specific therapy. It is a much less serious illness than bacterial or tubercular meningitis, unless there is associated encephalitis, which is rare. It occurs with acute onset headache and irritability. The headache is usually the more severe feature. Failure of a patient, with suspected viral meningitis, to improve within 48 hours should prompt a reevaluation. ${ }^{1}$

We wanted to evaluate the usefulness of CSF-ADA for rapid diagnosis and differentiation of tubercular \& viral meningitis in adults.

\section{METHODS}

\section{Study Design}

This is a prospective clinical evaluation study with the following diagnostic criteria for meningitis -

- Triad of fever, headache and nuchal rigidity

- Signs of meningeal irritation

- $\quad$ Altered mental status

- May be associated with vomiting and seizures.

Meningitis patients admitted and willing to give consent in the medicine department were included. Patients of age more than 18 years and having clinical signs and symptoms suggestive of meningitis were included in the study.

\section{Exclusion Criteria}

1. Age of patient less than eighteen years.

2. Patients with infections or inflammation at locations involving other systems, than the nervous system.
3. Patients where lumbar puncture is not possible.

4. With related significant liver dysfunction.

5. Females who are taking oral contraceptive drugs and intrauterine device.

6. Metabolic disorders.

7. Patients on steroid.

50 meningitis patients who fulfilled the inclusion criteria were included over a period of one year from October 2015 to September 2016. The sample size was taken based on the convenience of the study.

Written informed consent was taken from the patients. Demographic data, detailed history, physical \& systemic examination was recorded into proforma. Investigations including complete haemogram, LFT, RFT, RBS, serum electrolytes, HIV test, chest x-ray and CT brain (plain) were recorded. CSF cytology, biochemistry, gram stain, AFB stain \& culture were done.

These cases were further divided in to two groups based on clinical and CSF laboratory findings.

Group I: Tubercular meningitis consisted 30 of patients. Clinical features included insidious onset, with signs of meningeal irritation, may be associated with tuberculosis in other organs. CSF findings included proteins $>50 \mathrm{mg} / \mathrm{dl}$, sugar $<40 \mathrm{mg} / \mathrm{dl}$, cell count $>60$ cells / mm3 (predominantly lymphocytes), AFB stain or culture positive.

Group II: Viral meningitis consisted 20 of patients. Clinical features were acute in onset with signs of meningeal irritation. CSF findings included proteins $>45 \mathrm{mg} / \mathrm{dl}$, cell count $>25$ cells / mm3, (lymphocyte predominance), sugar level was normal. An estimation of CSF ADA was done for all the patients.

\section{Statistical Analysis}

Descriptive and inferential statistical analysis was done in the present study. Results on continuous measurements were obtained in mean SD ( $\min$ - max) and results on categorical dimensions were obtained in number (\%). Assessment of significance was done at $5 \%$ level of significance. The subsequent assumptions on data had been made. Assumptions - 1. Dependent variables should be normally distributed, 2 . Samples drawn from the population should be random, cases of the sample have to be independent. Statistical Analysis System (SAS) 9.2, Statistical Package for the Social Sciences (SPSS) 15.0, MedCalc9.0.1, Systat 12.0 and R environment ver.2.11.1 were used for the analysis of the figures and Microsoft Word and Excel was used to produce graphs, tables etc.

\section{RESULTS}

50 Meningitis patients who were admitted in Department of Medicine were included in this study. The mean age of the 50 patients studied was $37.76+15.58$ years. The youngest patient was 19 years old and oldest patient was 75 years. $56 \%(\mathrm{~N}=$ 28 ) of patients in the study were aged between $21-40$ years with the maximum number of patients $(\mathrm{N}=17)$ diagnosed with tubercular meningitis. In this study, $52 \%$ were males and $48 \%$ were females. Viral meningitis was more common in females compared to males. 


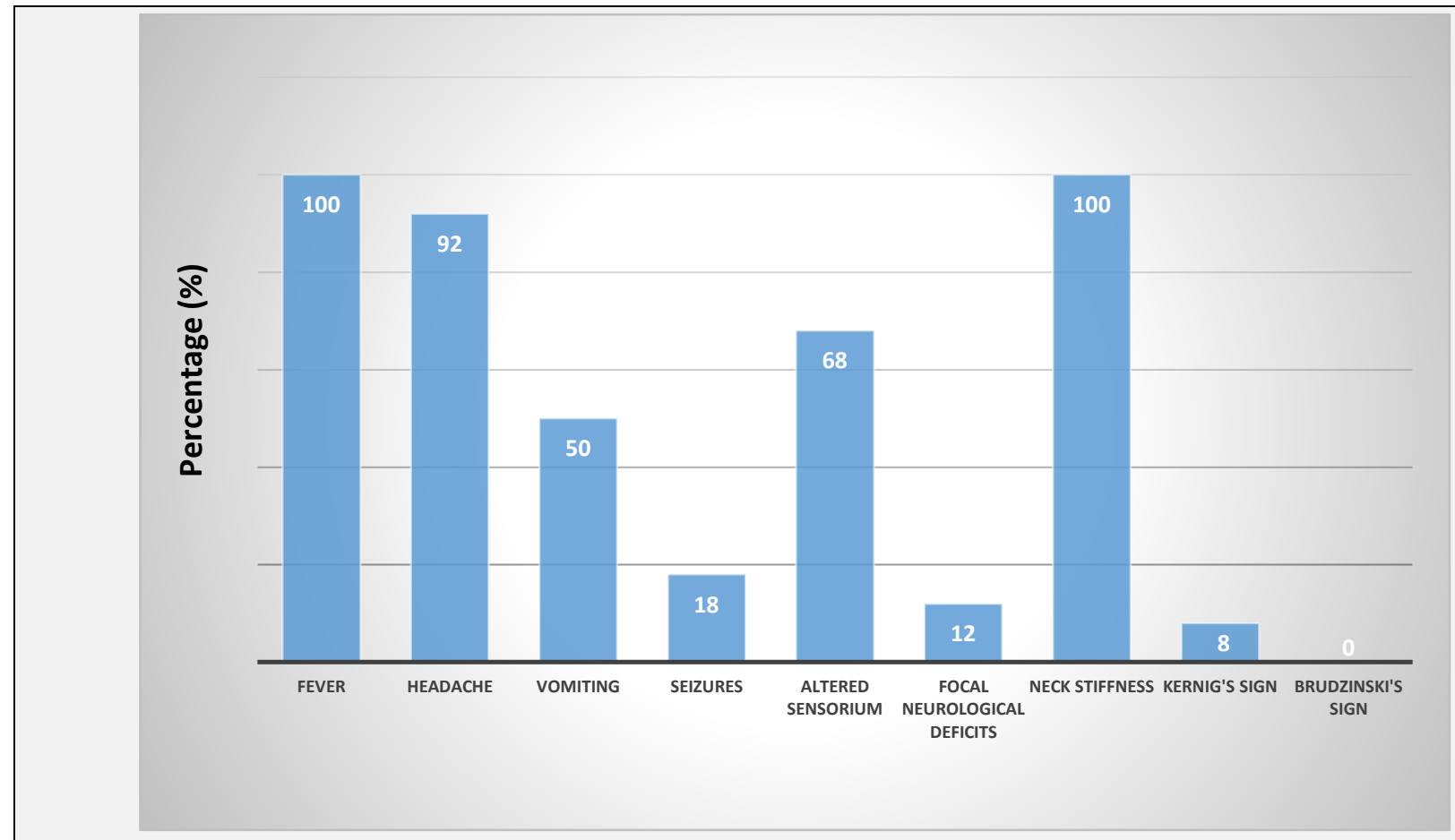

Figure 1. Clinical Presentation of Meningitis

\begin{tabular}{|ccccc|}
\hline Age (Years) & $\begin{array}{c}\text { Tubercular } \\
\text { Meningitis }\end{array}$ & $\begin{array}{c}\text { Viral } \\
\text { Meningitis }\end{array}$ & Total & $\begin{array}{c}\text { In Percentage } \\
\text { (\%) }\end{array}$ \\
\hline $18-20$ & 02 & 03 & 05 & 10 \\
$21-40$ & 17 & 11 & 28 & 56 \\
$41-60$ & 07 & 06 & 13 & 26 \\
$>60$ & 04 & 00 & 04 & 8 \\
Total & $\mathbf{3 0}$ & $\mathbf{2 0}$ & $\mathbf{5 0}$ & $\mathbf{1 0 0}$ \\
In percentage (\%) & 60 & 40 & 100 \\
\hline \multicolumn{5}{|c}{ Table 1. Age Distribution of Patients } \\
\hline \multicolumn{5}{|c}{} \\
\hline
\end{tabular}

\begin{tabular}{|ccccc|}
\hline Gender & $\begin{array}{c}\text { Tubercular } \\
\text { Meningitis }\end{array}$ & $\begin{array}{c}\text { Viral } \\
\text { Meningitis }\end{array}$ & Total & $\begin{array}{c}\text { Percentage } \\
\text { (\%) }\end{array}$ \\
Male & 19 & 07 & 26 & $52 \%$ \\
Female & 11 & 13 & 24 & $48 \%$ \\
Total & $\mathbf{3 0}$ & $\mathbf{2 0}$ & $\mathbf{5 0}$ & $\mathbf{1 0 0}$ \\
\hline \multicolumn{5}{c}{ Table 2. Gender Distribution of Meningitis } \\
\hline
\end{tabular}

\begin{tabular}{|ccc|}
\hline Type of Meningitis & Total No. & ADA (IU / L) Mean Value + SD \\
\hline Tubercular meningitis & 30 & $17.67 \pm 8.13$ \\
Viral meningitis & 20 & $1.89 \pm 0.55$ \\
\hline Table 3. Levels of CSF-ADA in Various Types of Meningitis \\
\hline
\end{tabular}

\begin{tabular}{|ccccc|}
\hline Type of & Total & \multicolumn{3}{c|}{ CSF-ADA Level ( > 10 IU / L) } \\
Meningitis & Number & Number & $\%$ & "P" Value \\
\hline $\begin{array}{c}\text { Tubercular } \\
\text { meningitis }\end{array}$ & 30 & 26 & 86.66 & $\mathrm{P}<0.001^{* *}$ \\
Viral meningitis & 20 & 00 & - & - \\
\hline \multicolumn{2}{|c|}{ Table 4. "P" Value of CSF-ADA in Different Types of Meningitis } \\
\hline
\end{tabular}

The incidence of meningitis was more in males. All patients of meningitis had fever and neck stiffness, followed by headache ( $92 \%$ ). About half of them had vomiting as a symptom. Focal neurological deficits were seen in 6 cases, all of them had tubercular meningitis. 9 patients presented with seizures, among which 6 were tubercular meningitis (TBM) \& 3 were viral meningitis. 34 patients presented with altered sensorium, among which 20 were in tubercular meningitis group. CSF-ADA level detected to be higher in tubercular meningitis, mean level was $17.67 \pm 8.13 \mathrm{IU} / \mathrm{L}$.

At CSF-ADA levels of $10 \mathrm{IU} / \mathrm{L}$, the sensitivity and specificity of ADA with respect to tubercular meningitis was $86.6 \%$ and $100 \%$ respectively, with an accuracy of $92 \%$.

\begin{tabular}{|ccccccc|}
\hline $\begin{array}{c}\text { Type of } \\
\text { Meningitis }\end{array}$ & $\begin{array}{c}\text { Total } \\
\text { No. }\end{array}$ & Sensitivity & Specificity & PPV & NPV & Accuracy \\
tubercular meningitis & 30 & $86.6 \%$ & $100 \%$ & $100 \%$ & $85.7 \%$ & $92 \%$ \\
viral meningitis & 20 & - & - & - & - & - \\
\hline \multicolumn{6}{|c|}{ Table 5. Diagnostic Performance of CSF-ADA } \\
\hline
\end{tabular}

\section{DISCUSSION}

Infections affecting the central nervous system, especially meningeal infections and brain parenchymal infections are expected to increase level of fear in both the diseased patient and treating doctor. In general, this is expected in view of high death rate linked with these diseases and the neurological sequelae that may remain in people who recover.

\section{CSF-Adenosine Deaminase}

From the present study, we found out that CSF-ADA level was significantly greater in tubercular meningitis as compared with viral meningitis. The mean value of ADA was $(17.67 \pm$ $8.13 \mathrm{IU} / \mathrm{L}) \mathrm{Z}=12.38 \mathrm{P} \leq 0.001$ in tubercular meningitis which is statistically significant. Mean ADA level in viral meningitis was $1.89 \pm 0.55 \mathrm{IU} / \mathrm{L}$.

By comparing the CSF-adenosine deaminase levels in the two groups, the analytical variation was detected to be statistically significant $(\mathrm{P}<0.001)$ in the tubercular meningitis sample of patients in comparison to viral meningitis. The sensitivity and specificity of CSF-ADA was $86.6 \%$ and $100 \%$ respectively.

In humans, the maximum adenosine deaminase activity is found in thymus and other lymphoid tissues ( $800 \mathrm{IU} /$ L) and the minimal possible activity in erythrocytes ( $\sim 1$ IU / L). Among non-lymphoid tissues in human beings, comparatively higher level of adenosine deaminase is found in the villi of epithelial cells coating the duodenum, but the 
levels are lesser in the other portions of the gastrointestinal tract. Tissues for example muscle, liver, kidney, brain and blood have low activity in most species. The activity of adenosine deaminase is variable to changes depending upon the level of activity of the cell i.e. whether differentiation or proliferation occurs. ${ }^{5}$

Some studies have reported a lower efficacy of this test and show an overlap between tuberculosis meningitis and bacterial meningitis. ${ }^{6}$

Malan $\mathrm{C}$ et al. showed that in both bacterial and TBM groups, the mean ADA level in the CSF was significantly higher than in aseptic meningitis $(P<0.001)$, but a significant difference was not shown between bacterial meningitis and TBM groups. ${ }^{7}$

Gambhir IS et al. found that the mean CSF ADA levels in TBM patients was $9.61 \pm 4.10 \mathrm{U} / \mathrm{l}$ and was significantly elevated as compared to viral encephalitis and enteric encephalopathy cases; but the difference was insignificant in comparison to pyogenic meningitis and cerebral malaria. ${ }^{8}$

From above discussion, higher level of CSF-ADA level in meningitis patients highly suggest tubercular meningitis.

\section{CONCLUSIONS}

CSF-ADA is an important laboratory investigation for early diagnosis and differentiation of tubercular and viral meningitis. It is essential when gold standard investigations for meningitis like smear and / or culture for microorganisms are unavailable or negative or are time consuming. The investigation for CSF-ADA is easy and straight forward and will be done in every laboratory with an early diagnosis, thus minimizing unnecessary or less useful treatment for disease. CSF-ADA is found to be higher in patients with tubercular meningitis compared to viral meningitis.
Data sharing statement provided by the authors is available with the full text of this article at jemds.com.

Financial or other competing interests: None.

Disclosure forms provided by the authors are available with the full text of this article at jemds.com.

\section{REFERENCES}

[1] Roos KL, Tyler KL. Harrison's Principles of Internal Medicine. Vol. 164. 19th edn. New York: McGraw-Hill Publication 2015: p. 883-906.

[2] Kashyap RS, Kainthla RP, Biswas SK, et al. Rapid diagnosis of tuberculous meningitis using the simple Dot Elisa method. Med Sci Monit 2003;9(11):123-6.

[3] Kashyap RS, Agarwal NP, Chandak NH, et al. The application of mancini technique as a diagnostic test in CSF of tuberculous meningitis patients. Med Sci Monit 2002;8(6):MT95-8.

[4] Raviglione MC. Harrison's Principles of Internal Medicine. 19th edn. Vol. 202. New York: McGraw-Hill Publication 2015: p. 1102-22.

[5] Franco R, Valenzuela A, Luis C, et al. Enzymatic and extraenzymatic role of ectoadenosine deaminase in lymphocytes. Immunol Rev 1998;161:27-42.

[6] Chawla RK, Seth RK, Raj B, et al. Adenosine deaminase levels in cerebrospinal fluid in tuberculous and bacterial meningitis. Tubercle 1991;72(3):190-2.

[7] Malan C, Donald PR, Golden M, et al. Adenosine deaminase levels in cerebrospinal fluid in the diagnosis of tuberculous meningitis. J Trop Med Hyg 1984;87(1):3340.

[8] Gambhir IS, Mehta M, Singh DS, et al. Evaluation of CSFadenosine deaminase activity in tubercular meningitis. J Assoc Physians India 1999;47(2):192-4. 